\section{Marko}

Radovan

Andragoški center

Slovenije

\title{
OVIRE ODRASLIH PRI VKLJUČEVANJU V IZOBRAŽEVANJE
}

Kot vemo, postaja vseživljenjsko učenje v modernih zahodnih družbah vedno pomembnejši sestavni del ekonomskega in družbenega razvoja. Danes je že splošno sprejeto dejstvo, da so zaloge znanja, ki jih posameznik pridobi $v$ formalnem začetnem izobraževanju, nezadostne in je zato potrebno znanje nadgrajevati tudi $v$ nadaljevalnem izobraževanju. Vseživljenjsko učenje ne pomeni samo brisanja meja med začetnim in nadaljevalnim izobraževanjem, temveč tudi vse večjo povezanost med učenjem na delu in učenjem v prostem času.

Raziskave kažejo, da je udeležba v nadaljnjem izobraževanju zelo povezana s socialno-

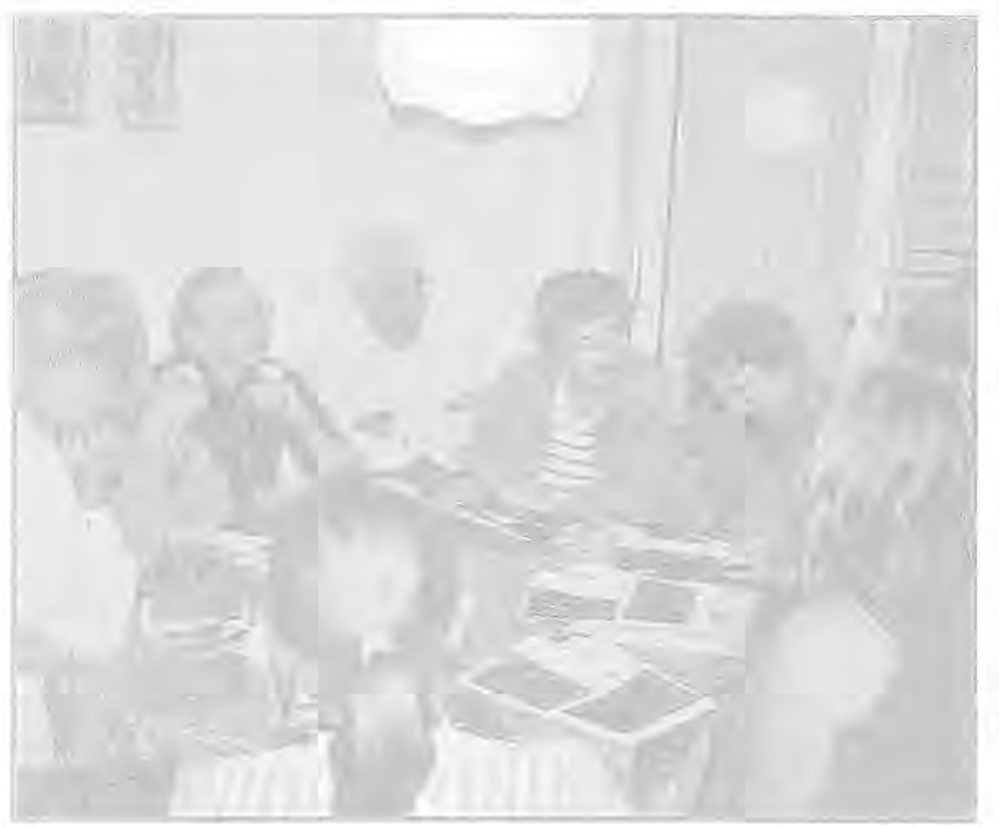

ekonomskim položajem posameznika. Če pogledamo deleže izobraževanja glede na namen in deleže tistih subjektov, ki izobraževanje financirajo, ugotovimo, da pri prvih prevladuje izobraževanje za potrebe poklica, pri drugih pa delodajalec kot poglavitni spodbudnik nadaljnjega izobraževanja (Radovan, 2001). Vse raziskave o značilnostih udeležbe odraslih $\mathrm{v}$ izobraževanju kažejo podobne trende: $v$ izobraževanje se najpogosteje vključujejo odrasli, ki prihajajo iz višjih socio-ekonomskih skupin, imajo več izobrazbe in zasedajo delovna mesta, ki zahtevajo in spodbujajo dodatno izobraževanje. Glede na ta spoznanja lahko trdimo, da so motivi odraslih za izobraževanje bolj instrumentalne kot pa ekspresivne narave, saj je udeležba $\mathrm{v}$ izobraževanju večinoma povezana $\mathrm{z}$ doseganjem določenega cilja (večinoma izboljšanjem poklicnega in posledično ekonomskega položaja posameznika). Pragmatičnosti izobraževanja odraslih navkljub pa vseeno drži dejstvo, da mora biti posameznik motiviran, da svoj poklicni in ekonomski položaj izboljša $\mathrm{z}$ vključitvijo $\mathrm{v}$ izobraževanje. Kot vemo, se posamezniku na podlagi neposrednih in posrednih izkušenj, ki jih pridobiva z življenjem $v$ določeni socialni sredini, oblikujejo prepričanja, stališča, vrednote itn., na podlagi katerih načrtuje svojo življenjsko pot in jo bolj ali manj uspešno uresničuje. V zvezi s tem je Courtney (1992) z analizo nekaterih klasičnih raziskav o 
participaciji odraslih $v$ izobraževanju prišel do sklepa, da deluje izobraževanje odraslih kot kontinuiteta formalnega šolanja, saj se vanj vključujejo predvsem tisti, ki so bili uspešni že v rednem šolanju. Courtney zato trdi, da je formalno izobraževanje odraslih bolj posledica kot pa sredstvo ekonomske moči; v njem prevladujejo predvsem tisti posamezniki, ki so že uspešni, manj pa tisti, ki si uspešni šele želijo postati.

\section{OVIRE PRI VKLJUČEVANJU V IZOBRAŽEVANJE}

Že iz naslova prispevka je jasno, da se bomo v njem ukvarjali z odkrivanjem ovir odraslih, ki so se želeli izobraževati, pa se zaradi takih ali drugačnih razlogov niso. V prispevku se bomo torej osredotočili na tiste odrasle, ki si (po Courtneyu) "uspešni šele želijo postati". $\mathrm{Za}$ to populacijo je morda ugotavljanje ovir celo pomembnejše kot poznavanje njihovih motivov.

Ovire delimo glede na mesto njihovega izvora: so bolj notranje (subjektivne, dispozicijske ...) ali bolj zunanje (objektivne, socialne ...) narave. $V$ andragoški literaturi je najbolj uveljavljena metodologija delitve ovir, ki jo je oblikovala Patricia Cross. Razvršča jih $v$ tri skupine: situacijske, institucionalne in dispozicijske (Cross, 1981).

- Situacijske ovire izhajajo iz posameznikovega trenutnega položaja in se izražajo v pomanjkanju casa, denarja, oddaljenosti kraja izobraževanja itd.

- Institucionalne ovire so predvsem tiste ovire, ki se tičejo neustrezne ponudbe izobraževalnih programov, vpisnih pogojev, neprilagojene organizacije, pomoči pri izobraževanju ipd.

- Dispozicijske ovire se povezujejo s psihosocialnimi značilnostmi posameznika, kot so samopodoba, stališča, motivacija, sposobnosti itd.

Tudi $v$ raziskavi Pismenost in udeležba odraslih v izobraževanju (1998) je bilo nekaj pozornosti namenjene ugotavljanju ovir. Spraševali smo o (a) ovirah, ki so preprečevale udeležbo anketiranega $\mathrm{v}$ izobraževalnih programih, $\mathrm{ki}$ prispevajo $\mathrm{k}$ njegovemu poklicnemu razvoju, kot tudi o (b) ovirah, ki so preprečevale izobraževanje, povezano $\mathrm{z}$ osebnimi interesi respondenta. Vprašanja so bila namenjena vsem anketirancem - tistim, ki so se $\mathrm{v}$ zadnjem letu že izobraževali ali se še izobražujejo, in udeležba $v$ izobraževanju je povezana z doseganjem dolocenega cilja. tistim, ki se izobraževanja niso udeležili.ı

Najprej si oglejmo rezultate glede motiviranosti odraslih, da bi se izobraževanja sploh udeležili. ${ }^{2}$

Kot je razvidno iz grafa 1 , se je $v$ referenčnem letu želelo za potrebe poklica izobraževati 22 odstotkov odraslih, za osebne potrebe pa 17 odstotkov odraslih. Če anketirance obravnavamo glede na njihovo izobraževalno aktivnost, ugotovimo, da je več kot tretjina izobraževaIno dejavnih odraslih navedla, da

Graf 1:

Pripravljenost za udeležbo v izobraževanju glede na dejavnost odraslih v izobraževanju in vrsto izobraževanja (v \%)
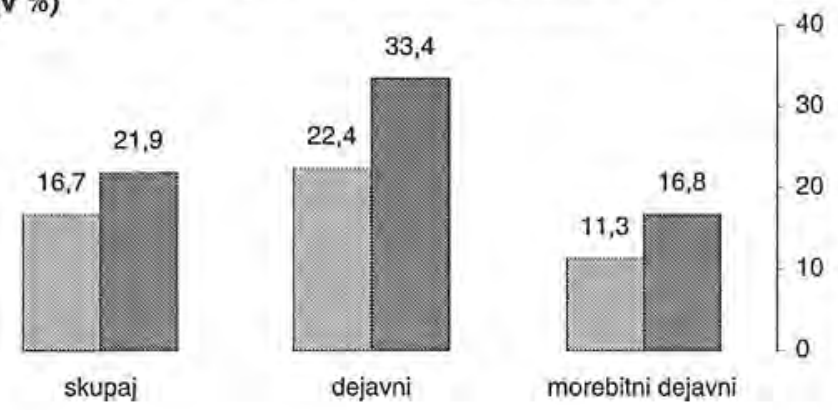

poklic 
se je v referenčnem časovnem obdobju želela izobraževati $\mathrm{v}$ zvezi $\mathrm{z}$ delom, petina pa $\mathrm{v}$ zvezi $\mathrm{z}$ izobraževanjem za osebne potrebe, Delež tistih anketirancev, ki se niso izobraževali, je v primerjavi $\mathrm{z}$ aktivnimi pri obeh vrstah izobraževanja za polovico manjši. $\mathrm{Ob}$ tem rezultatu se lahko spomnimo ugotovitve Rubensona (1978), da je najboljši prediktor izobraževanja $v$ prihodnosti prejšnje izobraževanje (Courtney, 1992).

Kot sem že dejal, je z vidika prilagajanja vsebin izobraževanja in izobraževalne ponudbe pomembno predvsem poznavanje ovir tistih odraslih, ki se $\mathrm{v}$ referenčnem letu niso izobraževali, bili pa so motivirani za to. V nadaljevanju so bile zato opravljene analize le za podvzorec morebitno dejavnih odraslih (n = 707).

$\mathrm{Na}$ grafu 2 so prikazani deleži ovir, zaradi katerih se anketiranci niso udeležili izobraževanja ( $v$ raziskavi je bila uporabljena lestvica desetih ovir).

Podatki kažejo, da so najpomembnejše ovire, ki so odraslim preprečevale udeležbo v izobraževanju, situacijske, sledijo jim organizacijske in dispozicijske. Med situacijskimi ovirami prevladujejo tiste, ki so povezane s časovno razpoložljivostjo: "splošno pomanjkanje časa", "prevelika zaposlenost na delovnem mestu", "družinske obveznosti" in "časovna neprimernost izobraževanja" zajemajo več kot polovico vseh odgovorov. Te ovire so pogostejše pri izobraževalno aktivnih odraslih. Prav tako pomembna situacijska ovira je "pomanjkanje denarja", ki je po pomembnosti uvrščna na drugo mesto. Ugotovimo torej lahko, da so tri četrtine vseh ovir situacijske. Med organizacijskimi ovirami je vredno opozoriti na ponudbo izobraževanja, ki jo očitno velik delež morebitno aktivnih odraslih zaznava kot pomanjkljivo. Delež dispozicijskih ovir je najmanjši, saj obsega le 6 odstotkov odgovorov.

$\mathrm{V}$ nadaljevanju bomo primerjali ovire $\mathrm{z}$ nekaterimi socio-demografskimi značilnostmi anketirancev. Zaradi ekonomičnosti bomo obravnavali le štiri ovire $z$ največjim deležem odgovorov. Te so naslednje:

- (splošno) pomanjkanje časa (29\%),

- finančne ovire (pomanjkanje denarja/ predrago izobraževanje; $21 \%$ ),

- družinske obveznosti (13\%) in

Graf 2:

Ovire pri izobraževanju (vse izobraževanje, v \%)

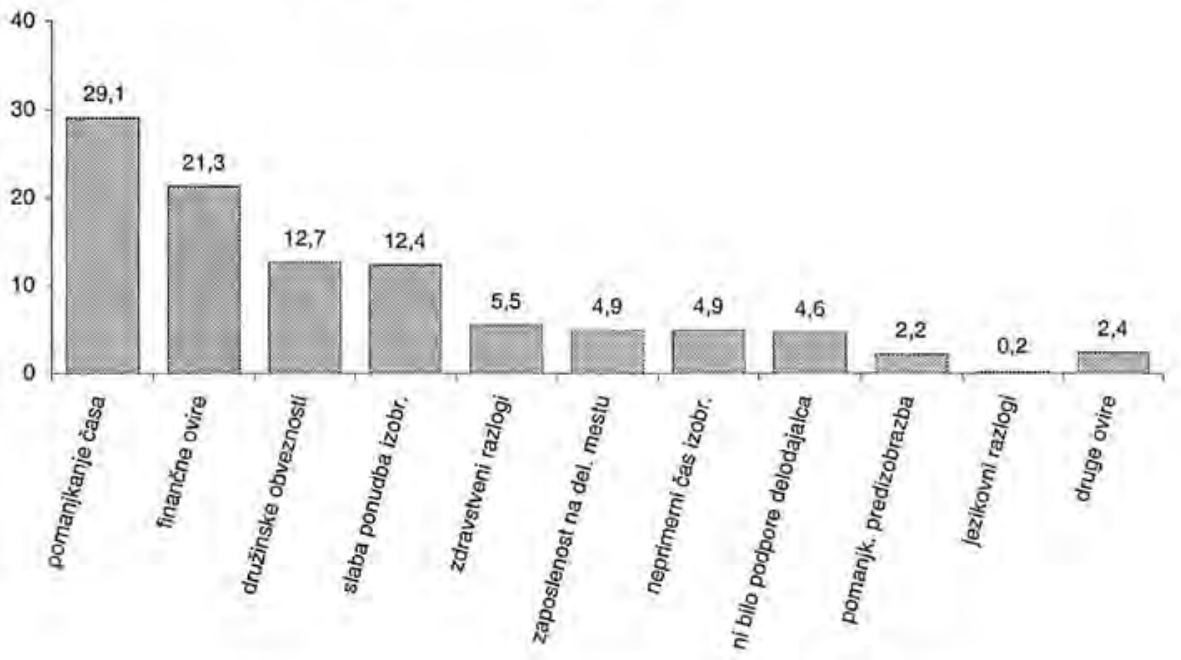


- pomanjkljiva izobraževalna ponudba (12 $\%)$.

Najprej si oglejmo ovire po spolu (graf 3).

Iz grafa 3 vidimo, da je pomanjkanje časa na prvem mestu med ovirami tako pri ženskah kot pri moških. Kljub enakemu rangu je razvidno, da predstavlja pomanjkanje časa večjo oviro moškim kot ženskam. Med spoloma ni opaziti večjih razlik $v$ ovirah, $z$ izjemo ene: družinske obveznosti. Ta preprečuje uresničitev motivov za izobraževanje skoraj petini žensk. Pri moških je delež te ovire zanemarljiv.

Primerjava ovir po starosti (graf 4) pokaže, da je pomanjkanje časa tudi pri vseh starostnih kategorijah najpomembnejša ovira.

Pomanjkanje časa zavzema največji delež pri odraslih, ki so starejši od 60 let, sledijo pa jim odrasli v starostni skupini do 25 let. Glede finančnih ovir je opaziti, da njihova pomembnost s starostjo pada. Največji delež zavzemajo finančne ovire pri najmlajši starostni kategoriji, najnižji pa pri najstarejši. Kar se tiče izobraževalne ponudbe, bi lahko rekli, da je situacija obrnjena. Pomanjkljiva izobraževalna ponudba je najmanj "problematična" za anketirance, ki so uvrščeni v starostno kategorijo do 25 let, najbolj pa jo omenjajo v starostnih skupinah od 41 do 60
Graf 3:

Ovire glede na spol (vse izobraževanje, v \%)

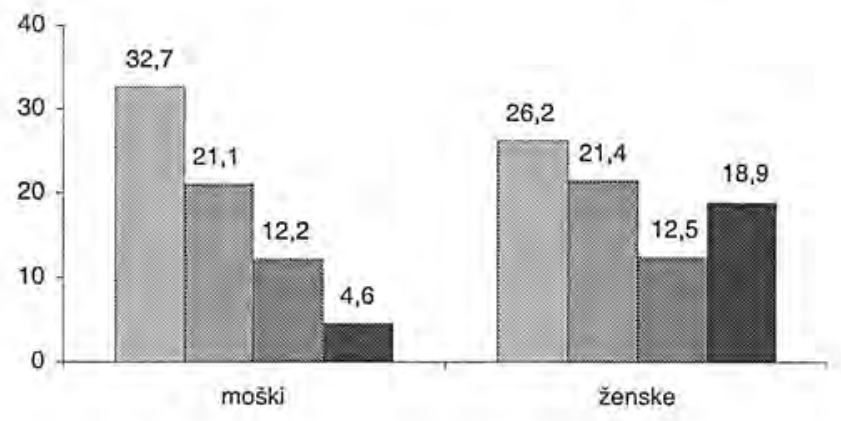

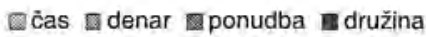

let in nad 60 let. Družinske obveznosti so najbolj izpostavljene $v$ starostni skupini od 26 do 40 let in pri starejših od 60 let.

Graf 5 kaže ovire odraslih glede na ekonomski položaj.

Primerjava ovir glede na zaposlitveni položaj pripelje do naslednjih ugotovitev:

- Časovna ovira je najizrazitejša pri kmetovalcih, na prvo mesto pa jo postavljajo tudi zaposleni in upokojenci.

- Finančni stroški izobraževanja preprečujejo udeležbo $v$ izobraževanju predvsem brezposelnim; visok delě̌ ima ta ovira tudi pri

\section{Graf 4:}

Ovire glede na starost (vse izobraževanje, v \%)








gospodinjah.

- Slaba izobraževalna ponudba je najpogosteje omenjan vzrok za neudeležbo pri upokojencih, brezposelnih in gospodinjah.

- Družinske obveznosti so za gospodinje najpomembnejši razlog za neudeležbo v izobraževanju.

$\mathrm{Na}$ koncu si oglejmo še, kakšne ovire navajajo anketiranci glede na njihov delovni položaj (graf 6).

- Čas je ovira, ki jo najpogosteje navajajo vse kategorije odraslih. Še posebej je ta ovira izpostavljena pri pomagajočih družinskih članih ter samozaposlenih.
- Finančne razloge najpogosteje navajajo delavci brez nadzorne moči, najredkeje pa pomagajoči družinski člani.

- Izobraževalna ponudba je na drugem mestu po pomembnosti pri pomagajočih družinskih članih, z zanemarljivim deležem pa je zastopana pri samozaposlenih.

- Družinske obveznosti imajo pri vseh delovnih kategorijah podobne deleže.

\section{INTERPRETACIJA IN ZAKLJUČEK}

Iz predstavljenih podatkov povzemamo, da izobraževalno dejavni odrasli zaznavajo večje potrebe po dodatnem izobraževanju kot morebitno dejavni odrasli. To velja tako za

\section{Graf 6:}

Ovire glede na polożaj na delovnem mestu (vse izobraževanje, v \%)

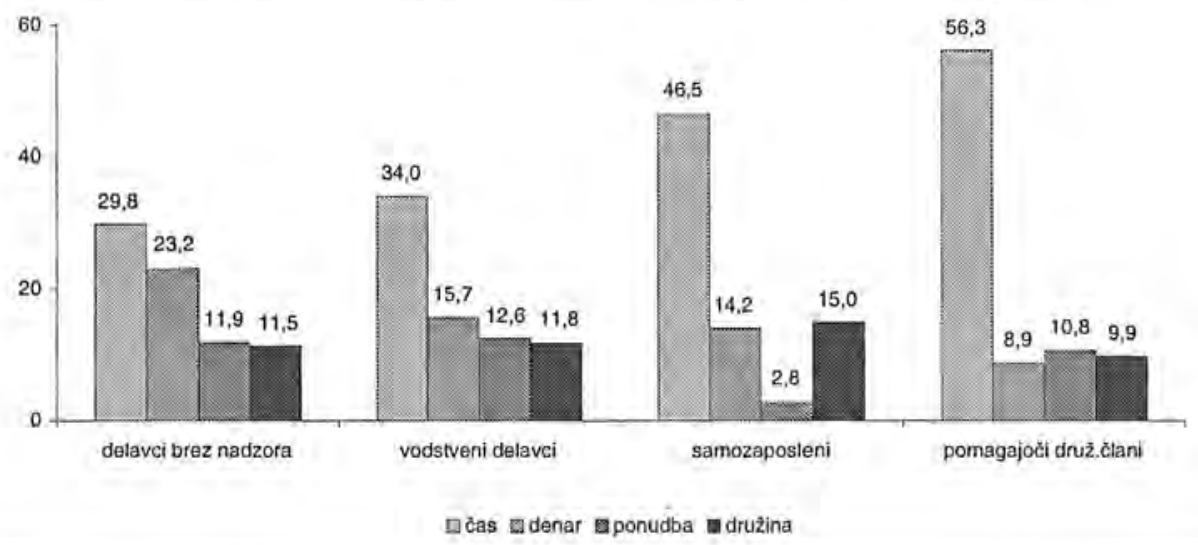


izobraževanje, povezano $\mathrm{z}$ delom, kot za izobraževanje, kjer prevladujejo osebni motivi.

Glede druge najpogosteje omenjane ovire "pomanjkanje denarja/predrago izobraževanje" (21\%) - smo ugotovili, da ni razlik med spoloma. Finančna plát izobraževanja najbolj ovira mlajše od 25 let, brezposelne in delavce brez nadzorne odgovornosti. Za denarne ovire je značilno, da s stopnjo izobrazbe in zahtevnostjo delovnega mesta njihov delež pada, saj imajo ti posamezniki veliko večje možnosti pridobitve subvencioniranega izobraževanja. Glede na navedene ugotovitve in dejstvo, da je večina izobraževanja odraslih povezana s svetom dela, lahko sklepamo, da je udeležba $\mathrm{v}$ izobraževanju velikokrat pogojena $\mathrm{s}$ pripravljenostjo in interesom delodajalca, da investira sredstva $v$ izobraževanje zaposlenega. Primerjava med vključenostjo $v$ izobraževanje in nosilci finančne podpore izobraževanja je pokazala, da imajo največje možnosti za delodajalčevo finančno podporo izobraževanju odrasli v "srednjih letih" (od 26 do 40 let), ki so zaposleni, imajo višjo stopnjo izobrazbe ter zasedajo vodstvena oz. vodilna delovna mesta (Radovan, 2001). Naslednji dve zelo pomembni oviri uvrščamo med situacijske oz. institucionalne ovire. Družinske obveznosti je navedlo 13 odstotkov anketirancev; kot veliko oviro jih navajajo ženske, anketiranci starejši od 60 let, gospodinje in samozaposleni. Kot smo videli iz analize, se kot pomembna ovira kaže tudi izobraževalna ponudba. Ta ovira ima 12odstotni delež. Med spoloma pri njej ni bilo razlik, po starosti jo najviše uvrščajo anketiranci starejši, od 60 let, glede na zaposlitveni položaj pa upokojenci. Rezultat je pričakovan, saj je značilno, da začne s starostjo naraščati udeležba $\mathrm{v}$ izobraževalnih programih, bolj vezanih na določeno prostočasno dejavnost. Zato so starejši socialna skupina,
Med navedenimi ovirami prevladujejo situacijske ovire, sledijo pa jim institucionalne in dispozicijske. Najpogosteje navedena ovira je "pomanjkanje časa". Kot enega od razlogov za neudeležbo v izobraževanju jo je navedlo 29 odstotkov odraslih. S pomanjkanjem časa in preveliko zaposlenostjo imajo največ tě̌av predvsem moški, mlajši od 25 let, zaposleni in upokojenci, med zaposlenimi pa samozaposleni, pomagajoči družinski člani in delavci na vodilnih delovnih mestih.

ki bolj "občuti" pomanjkljivo ponudbo izobraževanja. Iz analize je razvidno tudi, da dosegajo dispozicijske ovire zelo majhne deleže $\mathrm{v}$ primerjavi $\mathrm{z}$ ostalimi ovirami. Ta podatek je do neke mere presenetljiv, saj je veliko tovrstnih raziskav pri interpretaciji usmerjenih prav k ugotavljanju dispozicijskih razlogov udeležbe $v$ izobraževanju. Majhen delež dispozicijskih ovir v naši raziskavi se da lahko pojasniti: na lestvici desetih ovir sta le dve dispozicijski (zdravje in jezik), ki med ostalimi nimajo večjega pomena. Med morebitno dejavnimi anketiranci se zaradi zdravstvenih razlogov izobraževanja ni udeležilo 6 odstotkov vprašanih; delež odraslih, ki so navedli jezikovne ovire, se je izkazal za zanemarljivega $(0,2 \%)$. Jezikovne ovire za izobraževanje so v Sloveniji očitno zelo majhne (vsaj za odrasle, ki bi se želeli izobraževati). Glede na to, da je bil uporabljen vprašalnik večkrat preizkušen in standardiziran, ${ }^{3}$ se lahko vprašamo, zakaj je tako. Eden od možnih odgovorov bi lahko bil, da so izsledki podobnih raziskav $v$ tujini (McGivney, 1990) pokazali, da odrasli včasih ne zmorejo, včasih pa nočejo "priznati" odklonilnega odnosa do izobraževanja. Zaradi tega, ker je ugotavljanje dispozicijskih ovir težavno opravilo, so dispozicijske trditve pri lestvicah ovir velikokrat kar izpuščene. Glede na ta spoznanja je potrebna pazljivost pri interpretaciji ostalih ovir. McGivney (1990) opozarja, da so ovire, ki jih navajajo odrasli, mnogokrat le racionalizacija doIočene dejavnosti "za nazaj". Najpogosteje
AS $10,9 \pi$ 
navedene ovire, kot so "pomanjkanje časa", "prezaposlenost na delovnem mestu", "predrago izobraževanje" in podobne, se s poglobljenimi analizami hitro relativizirajo.

Poveča se predvsem stopnja gledanosti televizije - zlasti neizobraževalnih programov (Rubenson, 1986; cit. po McGivney 1990). Znano je tudi dejstvo, da je največ $v$ izobraževanju aktivnih odraslih prav tistih, $\mathrm{ki}$ so časovno najbolj obremenjeni. Do podobnih ugotovitev pridemo tudi pri "rekonstrukciji" druge najpomembnejše ovire - "pomanjkanje denarja". Stroški izobraževanja so za ekonomsko ogrožene posameznike brez dyoma zelo pomemben dejavnik, ki vpliva na odločitev za vključitev $\mathrm{v}$ izobraževanje. To oviro do neke mere relativizira spoznanje, da imajo anketiranci, ki so jo navedli, zelo slabo védenje o tem, koliko določeno izobraževanje sploh stane, kakšne so možnosti subvencioniranja izobraževalnih programov itd. (ALF Report on AE in Newcastle-upon-Tyne, 1987; cit. po McGivney, 1990)، Cross (1981) tudi opozarja, da so finančni stroški družbeno najsprejemljivejši razlog, da se neke dejavnosti ne lotevamo oz. jo opustimo. Dispozicijske ovire so torej pomembne, a največkrat "skrite" v situacijskih. Strokovnjaki, ki trdijo, da so razlogi za "odsotnost" iz izobraževanja predvsem psihološki (McGivney, 1990; Fuller \& Saunders, 1991; Quigley, 1997), navajajo, da ima velik del izobraževalno neaktivnih odraslih stereotipne predstave o izobraževanju odraslih. Ti stereotipi, ki izhajajo predvsem iz negativnih izkušenj v rednem izobraževanju, se skupaj s socialno-ekonomsko situacijo, v kateri se nahaja posameznik, "oblikujejo" v stališča, pričakovanja in percepcije posameznika $v$ zvezi z izobraževanjem, ki zaviralno vplivajo na njegovo motivacijo za učenje in izobraževanje. V večini primerov gre za predstave o neprimernosti posameznika kot učenca, nepomembnosti izobraževanja kot sredstva socialne mobilnosti, neizoblikovanih izobraževalnih potreb, negativnega odnosa do šole, pomanjkanje samozaupanja $v$ sposobnost učenja ipd. To še posebej velja za starejše, tiste, ki imajo nizko izobrazbo in odrasle $\mathrm{z}$ nizkim socialnim statusom.

Iz povedanega lahko povzamemo sklep, da so dispozicijske ovire (stališča, pričakovanja, samozaupanje in percepcija) izredno pomemben element, ki vpliva na pripravljenost odraslih, da investirajo svoj prosti čas, denar in energijo v izobraževanje. Zaradi svoje kompleksnosti so težko ugotovljive, zato rezultati, pridobljeni s pomočjo takšnih ali drugačnih ocenjevalnih lestvic, včasih ne dajo kristalno čiste slike o ovirah, ki odraslim preprečujejo udeležbo $\mathrm{v}$ izobraževanju. Njihovo preučevanje zato zahteva uporabo kvalitativnih metod, s katerimi bi laže rekonstruirali manj vidne ovire, ki odraslim znižujejo pripravljenost za udeležbo v izobraževanju.

Situacijske in institucionalne ovire pri vključevanju $v$ izobraževanje so pri neaktivni odrasli populaciji mnogokrat odraz predvsem treh značilnosti:

(a) vrednotenja izobraževanja, ki je povezano s specifičnimi stališči do izobraževanja, pričakovanji od izobraževanja itd.,

(b) neinformiranosti o možnostih, ki jih imajo v zvezi z izobraževanjem (cena izobraževanja, ponudba izobraževalnih programov, časovna razporeditev itd.),

(c) nizke ravni pismenosti, ki ima negativen vpliv na obe zgornji značilnosti. 


\section{LITERATURA}

Courtney, S. (1992). Why Adults Learn: Towards a Theory of Participation in Adult Education, London, Routledge.

Cross, K. P. (1981). Adults as Learners: increasing participation and facilitating learning. San Francisco, CA: Jossey-Bass Inc.

Fuller, A., Saunders, M. (1991). The potential takeup of mass training. V Winterburn R. (Ed.), Aspects of Educational and Training Technology. Vol. XXIV: Realizing Human Potential, Kogan Page, London, str. 295-300.

Jelenc, Z. (1989). Odrasli prebivalci Slovenije v izobraževanju. Ljubljana, Skupnost izobraževalnih centrov v Sloveniji: Pedagoški inštitut pri Univerzi Edvarda Kardelja.

McGivney, V. (1990). Education's for other people: access to education for non-participants adults: a research report. NIACE, Leicester.

Quigley, A. B. (1997). Rethinking literacy education: the critical need for practice-based change. San Francisco: Jossey-Bass.

Radovan, M. (2001). Finaněni vidiki motivacije odraslih za izobraževanje. IB revija, 35, 2-3, str, 36-44.

Raziskava Pismenost odraslih in udeležba $v$ izobraževanju, Andragoški center, 1998.

1 Preizkušance smo razdelili na tri skupine: dejavne udeležence $v$ izobruževanju, morebitne udeležence $v$ izobruževanju in nedejavne v izobraževanju. Dejavni udeleženci v izobraževanju so tisti, ki so odgovorili, da se v času anketiranja izobražujejo oz. so se izobraževali $v$ zadnjih dvanajstih mesecih pred anketiranjem. Morebitni dejavni udeleženci so tisti, ki so odgovorili, da se ne izobražujejo oz. da se v zadnjem letu niso izobraževali, bi se pa želeli izobraževati, če bi imeli možnosti za to. Nedejavni pa so vsi tisti, ki se v času anketiranja oz. $v$ zadnjih dvanajstih mesecih niso udeleževali izobraževanja, in tudi za naprej ne navajajo, da bi se želeli izobraževati (Jelenc, 1989).

2 Vobdelavo so bili zajeti anketiranci, stari od 16 do 65 let, ki so se izobraževali kot odrasli v izobraževalnih programih, daljsih od pet ur.

${ }^{3}$ Raziskava je bila del mednarodne raziskave, ki sta jo vodila Kanadski urad za statistiko (Statistics Canada) in Inštitut za testiranje v izobraževanju s Princetona $v$ ZDA (Educational Testing Service). 